\title{
Temporal and spatial variability of chroococcoid cyanobacteria Synechococcus spp. specific growth rates and their contribution to primary production in the Sargasso Sea*
}

\author{
R. Iturriaga ${ }^{1}$, J. Marra ${ }^{2}$ \\ ${ }^{1}$ Department of Biological Sciences, University of Southern California, Los Angeles, California 90089-0371, USA \\ ${ }^{2}$ Lamont-Doherty Geological Observatory of Columbia University, Palisades, New York 10964, USA
}

\begin{abstract}
The distribution, contribution to primary production and specific growth rates of the phycoerythrin-rich planktonic chroococcoid cyanobacteria Synechococcus spp. were studied in a transect along $70^{\circ} \mathrm{W}$ in the Northwest Atlantic during April 1985. Large subsurface maxima were observed between $32^{\circ} \mathrm{N}$ and $26^{\circ} \mathrm{N}$ ( 3 to 15 April). Abundances of cyanobacteria increased nearly 10 -fold at $35^{\circ} \mathrm{N}$ ( 3 to 5 April) over a $2 \mathrm{wk}$ period. The largest concentrations of Synechococcus were observed north of the Subtropical Front in the Sargasso Sea $\left(26^{\circ} \mathrm{N}\right)$. Primary production by Synechococcus varied between 3.4 and $11.8 \mathrm{fgC}_{\text {cell }}^{-1} \mathrm{~h}^{-1}$ with specific growth rates that ranged from 0.5 to $1.2 \mathrm{~d}^{-1}$ as determined by epifluorescence track autoradiography. Their contribution to total primary production (as measured by differential filtration) ranged from 60 to $95 \%$ of the total.
\end{abstract}

\section{INTRODICTION}

Recent research has indicated that phycoerythrinrich chroococcoid cyanobacteria of the genus Synechococcus are a significant component of the picoplankton (Waterbury et al. 1979, Johnson \& Sieburth 1979, 1982, Glover 1985). They are often the most abundant photoautotrophs in mesotrophic and oligotrophic regions, with cell concentrations ranging from $10^{3}$ to $10^{5}$ cells ml $^{-1}$ (Waterbury et al. 1979, Johnson \& Sieburth 1979, 1982, Krempin \& Sullivan 1981, Campbell et al. 1983, Murphy \& Haugen 1985).

Photosynthetic rates of Synechococcus spp. are likewise thought to be high, but are uncertain because rate measurements are typically estimated by means of size fractionation, and the cyanobacteria lumped within the picoplankton (size fraction $<3 \mu \mathrm{m}$ ). This fraction often accounts for between 45 and $60 \%$ of the total primary production (Li et al. 1983, Platt et al. 1983, Takahashi \& Bienfang 1983, Glover et al. 1986, Prézelin et al. 1986). More specific fractionation for Synechococcus spp. support the presumed high specific

- Lamont-Doherty Geological Observatory Contribution No. 4279; Biowatt Contribution No. 05 growth rates; howevel, few siudies have investigated the specific photosynthetic rates of Synechococcus spp. in the field. The only available information about specific ${ }^{14} \mathrm{C}$-uptake by Synechococcus in natural samples using epifluorescence nuclear-track autoradiography has been reported by Douglas (1984) for marine environments, and Fahnenstiel et al. (1986) for lakes. These investigations have also confirmed high photosynthetic and growth rates for Synechocococcus spp. The high specific growth rates implicate these cyanobacteria as a significant component of the microbial food web (Iturriaga \& Mitchell 1986).

The present study documents the spatial and temporal variability of Synechococcus spp. in the Sargasso Sea in spring 1985. We also estimate growth rates from 2 independent isotopic techniques, document the changes in abundance occurring at the same site over a 2 wk period, and estimate population losses.

\section{METHODS}

Experiments were performed during Biowatt $I$, a cruise from 3 to 26 April 1985 aboard the RV 'Knorr' in the Northwest Atlantic Ocean. Stations were located on 
a north-south transect along $70^{\circ} \mathrm{W}$ (Fig. 1). Routine hydrographic measurements were conducted at each station.

Counts of Synechococcus spp. were made from at least one hydrocast for all stations on the cruise. For Stns 04, 10 and 19 (Fig. 1), which were occupied for a period of 5 or more days each, samples were collected from 4 to 6 hydrocasts. Primary production experiments were performed at these long-duration stations; however, data for comparison of differential size fractionation with autoradiography are available only from Stns 10 and 19.

Water samples were assayed for Synechococcus spp. abundance by filtering onto $0.4 \mu \mathrm{m}$ Nuclepore filters (Hobbie et al. 1977) and counting the cells by epifluorescence microscopy (Watson et al. 1977). The samples were also examined for paired cells, indicating a stage in cell division. Measurements of primary production were made in water samples collected from 7 to 10 depths in the euphotic zone. Water samples were placed in $250 \mathrm{ml}$ polycarbonate bottles. $\mathrm{NaH}^{14} \mathrm{CO}_{3}$ was added, and the samples incubated in situ at their respective depths from dawn to dusk. A parallel set of samples was incubated for use in nuclear-track autoradiography as described below. ${ }^{14} \mathrm{C}$ stocks were prepared according to the trace-metal clean procedures outlined in Fitzwater et al. (1982). For chlorophyll a analyses we used the fluorometric method with $90 \%$ acetone extraction described in Smith et al. (1981), using a Turner 111 fluorometer which had been calibrated with pure chlorophyll a.

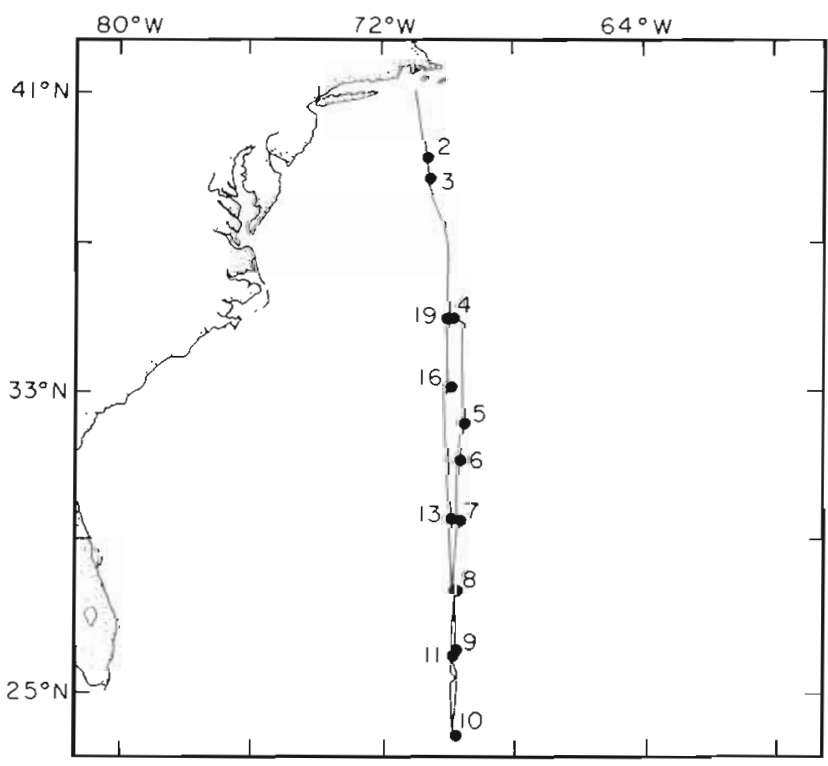

Fig. 1. Station locations in the Northwest Allantic for the cruise Biowatt I (3 to 26 April 1985). Stns 4 and 19 are in the Northern Sargasso Sea, and south and east of the Gulf Stream. Stn 10 is south of the sub-tropical convergence front (STC) (ca 26 N) and in the Southem Sargasso Sea
Primary production and growth rates of Synechococcus spp. were determined by 2 different procedures using the ${ }^{14} \mathrm{C}$ uptake technique. One approach combined filter fractionation and cell counts by epifluorescence microscopy (Iturriaga \& Mitchell 1986), and the other combined epifluorescence microscopy and nuclear-track autoradiography (Fuhrman \& Azam 1982, Fahnenstiel et al. 1986). A slight modification was introduced to this last procedure. After incubation, the samples were first screened through a $3 \mu \mathrm{m}$ Nuclepore filter (gravity pressure only) to eliminate larger phytoplankton cells. Small volumes $(25 \mathrm{ml})$ of the filtrate were then filtered through $0.4 \mu \mathrm{m}$ Nuclepore filters and rinsed 4 to 5 times with $5 \mathrm{ml}$ of $0.2 \mu \mathrm{m}$ filtered seawater to diminish the background from remnant $\mathrm{NaH}^{14} \mathrm{CO}_{3}$. The samples were not acidified or exposed to fixatives. Afterwards the cells were transferred, inverting the filters onto cover slips coated with a gelatin mixture (gelatin water $5 \% \mathrm{w} / \mathrm{v}$, glycerol $30 \% \mathrm{v} / \mathrm{v}$, sodium azide $0.2 \% \mathrm{w} / \mathrm{v}$ ) and then peeled off. These slides were stored frozen until prepared for nuclear-track autoradiography in the laboratory (Knoechel \& Kalff 1976). To minimize fading of the cells' natural autofluorescence the exposure time was limited to 1 to $3 \mathrm{~d}$ (Fahnenstiel ef al. 1986). Growth rates for Synechococcus spp. were calculated from carbon fixation values and expressed on a daily basis. Carbon content was estimated as a function of cell volume using the factor of

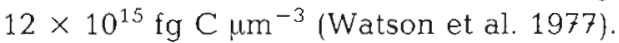

\section{RESULTS AND DISCUSSION}

\section{Synechococcus spp. abundances}

Major features of North Atlantic circulation are apparent from the north-south transect of temperature obtained by expendable bathythermographs (XBT) (Dickey et al. 1985; Fig. 2a). The north end of the transect, observed between $33^{\circ}$ and $35^{\circ} \mathrm{N}$, was characterized by a water mass of 18 to $19^{\circ} \mathrm{C}$. There was little stratification in temperatures, with differences less than 1 to $2 \mathrm{C}^{\circ}$ over the upper $200 \mathrm{~m}$. This probably represents the initial spring warming of the surface layer from the $18^{\circ}$ water representative of wintertime convective cooling in this region of the Sargasso Sea. To the south, the waters sampled in the transect exhibit greater stratification and warmer surface temperatures.

Another large-scale feature apparent in the XBT section (Fig. 2a) is the strong thermal front observed near $26^{\circ} \mathrm{N}$, the Sub-Tropical Convergence (STC). The STC divides the North from the South Sargasso Sea (Hulbert 1964), and indicates the southern limit of wintertime convective mixing (Worthington 1976). South of the STC, the observed stratification intensifies; here 
TEMPERATURE ( $\left.{ }^{\circ} \mathrm{C}\right)$

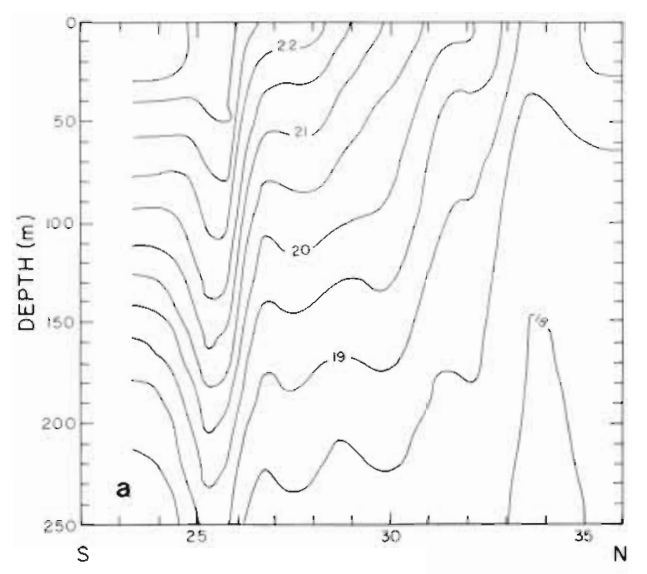

PAR $\{\%$ surfoce $\}$

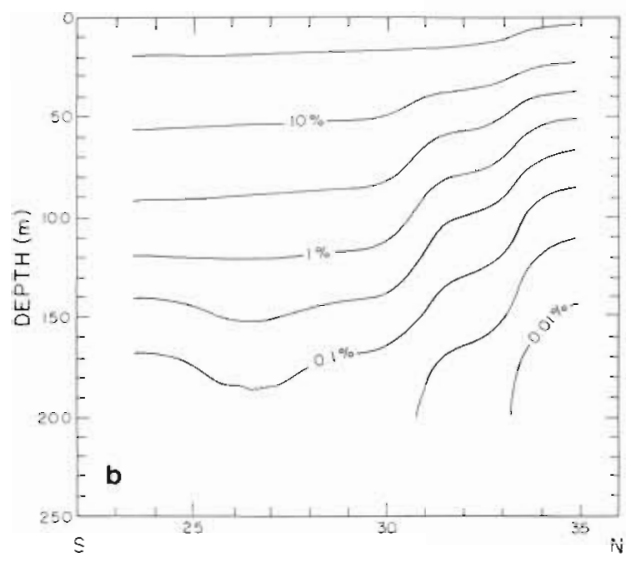

COCCOID CYANOBACTERIA (\#/ml)

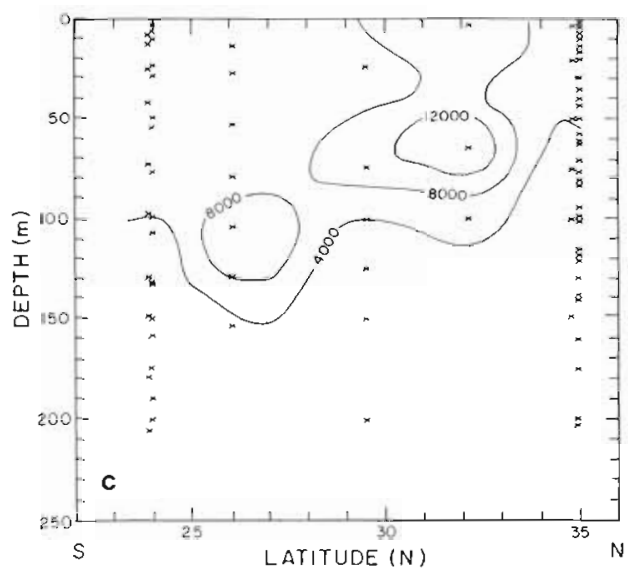

Fig. 2. (a) Temperature, (b) photosynthetically active irradiance (PAR), and (c) coccoid cyanobacteria, as a function of depth along the transect (Stns 4 to 10) shown in Fig. 1 (8 to 12 April 1985). Temperature data from expendable bathythermographs launched every $100 \mathrm{~km}$ along the transect. PAR $(\%$ surface value) computed from data collected by the Bio-Optical Profilings Systems (BOPS; Marra et al. unpubl.). In (c) sample depths are shown as $\mathrm{x}$; isopleths in cells $\mathrm{ml}^{-1}$ the depth of the mixed layer varied between 30 and $40 \mathrm{~m}$. The euphotic zone, as defined by the depth of penetration of $1 \%$ of surface irradiance $\left(I_{0}\right)$, also increases (Fig. 2b) indicating greater water clarity towards the south. The depth of the $1 \%$ irradiance level increases from between 50 and $60 \mathrm{~m}$ at $35^{\circ}$ to between 140 and $150 \mathrm{~m}$ at $24^{\circ} \mathrm{N}$.

Transects of Synechococcus spp. abundance measured from 3 to 15 April showed large changes both in abundances and depth distributions (Fig. 2c). Overall, cell number densities of Synechococcus spp. declined from north to south, and surface maxima gave way to subsurface maxima between $34^{\circ}$ and $26^{\circ} \mathrm{N}$, the general trend following the deepening of the isotherms. Peak abundances at $32^{\circ} \mathrm{N}$ were ca 14000 cells $\mathrm{ml}^{-1}$. A large gradient in cell number occurred just to the north of the STC, and it is possible that the STC represents a boundary for Synechococcus spp. It has previously been suggested that the STC is a partition between differing phytoplankton populations (Hulburt 1964). Our distribution data complement those of Murphy \& Haugen (1985). Their data for the North Atlantic range from 30 to $60^{\circ} \mathrm{N}$ for April and May, and show that abundance is apparently temperature dependent, with higher water temperatures showing higher numbers of cyanobacteria. In our data, this is only true north of the STC, and suggests that other factors such as nutrient supply via vertical mixing may affect oceanic distributions of cyanobacteria.

North of the STC, maximum cell abundances were observed in the upper $50 \mathrm{n}$ while south of the front $\left(24^{\circ} \mathrm{N}\right)$, maxima in cell abundances were observed near $100 \mathrm{~m}$ depth. Along this transect the deepening of the euphotic zone $\left(1 \% I_{0}\right)$ was also followed by the deepening of the abundance maxima. This supports previous observations suggesting that Synechococcus spp. may make their major contribution near the bottom of the euphotic zone ( $\mathrm{Li}$ et al. 1983, Platt et al. 1983), at least in well-stratified water columns.

Vertical profiles of Synechococcus spp. show this more clearly (Fig, 3). Here, vertical profiles of cell abundances are compared at 3 locations along the north-south transect (see Fig. 1). At the northernmost station (Stn 4; Fig. 3a) abundances are about 2000 to 9000 cells $\mathrm{ml}^{-1}$ within the euphotic zone with a maximum at $20 \mathrm{~m}$. South of the STC (Fig. 3d), cell numbers are quite low with a maximum at $100 \mathrm{~m}$. At Stn 19 (19 to 24 April; Fig. 3c), Synechococcus spp. abundances increase approximately 10 -fold when compared to Stn 4 earlier in the month (4 to $7 \mathrm{April}$; Fig. 3 a). For both periods maximal abundances were found between 20 and $30 \mathrm{~m}$ depth, lying near the depth of $10 \% I_{0}$.

The net-cumulative growth rate between these 2 periods is calculated as follows. First, mean euphotic zone concentrations were calculated according to 
STATION-CAST 4 - I9 5APRIL
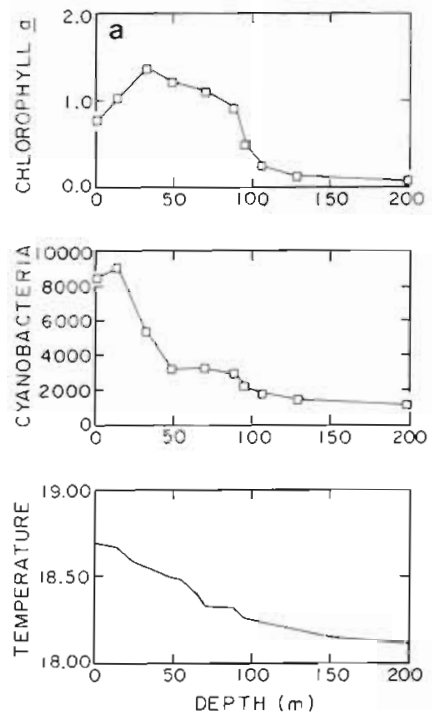

STATION-CAST $10-19 \quad 13$ APRIL
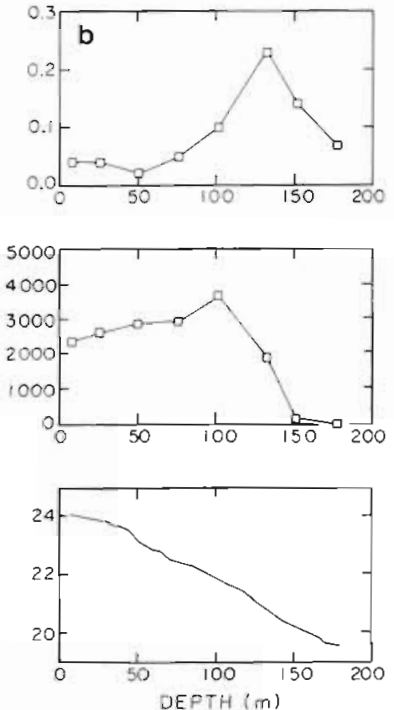

STATION-CAST $19-5022$ APRIL.
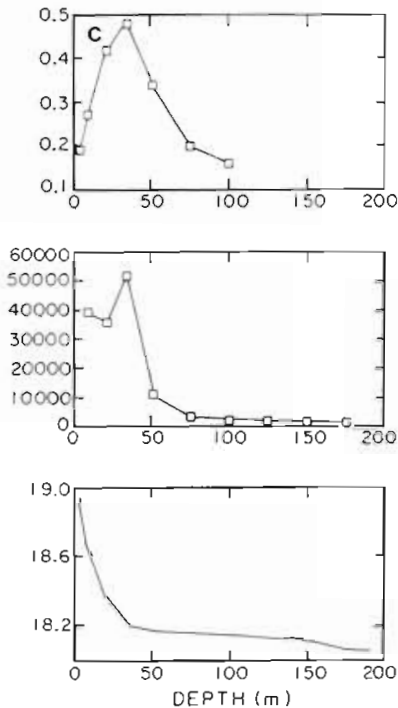

STATION-CAST $19-81$ 24 APRIL
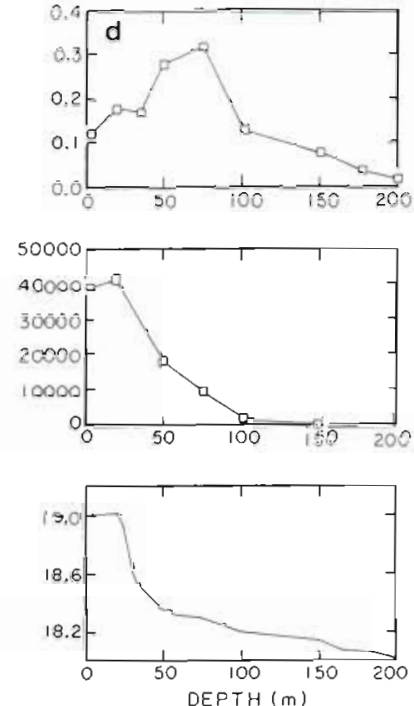

Fig. 3. Temperature $\left({ }^{\circ} \mathrm{C}\right)$, cyanobacteria $\left(\right.$ no. $\left.\mathrm{ml}^{-1}\right)$, and chlorophyll $a\left(\mu \mathrm{I} \mathrm{I}^{-1}\right)$ as a function of depth at (a) station-cast $4-19(5 \mathrm{April}$ 1985), (b) 10-19 (13 April), (c) 19-50 (22 April), and (d) 19-81 (24 April)

$$
N=\left(1 / z_{\mathrm{e}}\right) \int_{0}^{z_{\mathrm{e}}} N(z) \mathrm{d} z
$$

where $N(z)$ is the cell number at depth $z$; and $z_{\mathrm{e}}$ is the depth of the euphotic zone. Next, growth rates were calculated according to

$$
r_{\mathrm{ij}}=\left(1 / t_{\mathrm{ij}}\right) \ln \left(N_{\mathrm{j}} / N_{\mathrm{i}}\right)
$$

The subscripts $i$ and $j$ refer to hydrocasts taken during Stns 4 and 19, respectively; $t_{\mathrm{ij}}=$ time between these respective hydrocasts (in d); and $r_{\mathrm{ij}}$ is the net growth rate during time $t_{\mathrm{ij}}$. The $r_{\mathrm{ij}}$ 's were then averaged to produce the ensemble mean, $M_{1}$

$$
M=\sum_{\mathrm{k}=1}^{n} r_{\mathrm{ij}} / n
$$

The ensemble mean net growth, $M$, is $0.08 \mathrm{~d}^{-1}$ which corresponds to a doubling of cell number about every $8 \mathrm{~d}$. We evaluate this estimate of net-cumulative growth rate in the context of carbon assimilation and grazing in the sections below.

\section{Carbon assimilation}

Iturriaga \& Mitchell (1986) established that the Whatman 934-AH glass-fiber filter passed 50 to $60 \%$ of the total cyanobacterial population in the oligotrophic ocean, and also suggested that the filtrate contained almost pure (ca $90 \%$ ) cyanobacteria as autotrophs. This size fractionation would therefore be useful in photosymthetic studies of natural populations. For the Biowatt I cruise, post-incubation filtrations and subsequent cell counts showed that on average the 934-AH passed $58 \%$ of the cyanobacteria. Microscopic examination also showed that the filtrates were largely free of eucaryotic autotrophs. However, in some cases red fluorescing cells of similar size to Synechococcus were detected under the epifluorescence microscope. The presence of these small eucaryotes varied with sample location and depth. Iturriaga \& Mitchell (1986) reported that the 934-AH filtrates in some cases contained up to $10 \%$ of small red-fluorescing eucaryotes. Under the epifluorescence microscope, a taxonomic identification of these cells is not feasible. Differential filtration is a fast and easy procedure to estimate photosynthetic rates of a determined size class; however, a discrete fractionation without contamination of different cells with approximate size is not possible. This may explain in part the higher rates observed in the size-fractionated samples when compared with the single-cell rates determined by nuclear track autoradiography discussed below

The contribution of cyanobacteria to the total primary production was calculated assuming that the rate found for the cyanobacteria passing the 934-AH filter could be extrapolated to those retained by that filter. Therefore the carbon assimilation per cyanobacterium in the post-incubation filtrates was multiplied by the logarithmic mean of the total population enumerated prior to, and after, the in situ incubation. As mentioned above, this procedure will overestimate the contribution of cyanobacteria to total primary production since other small autotrophs will also pass the 934-AH. The magnitude of this overestimate will be considered below with the autoradiographic data. It is useful to mention at this point that the sum of primary produc- 
tion in the respective size fractions was always close to the unfractionated (total), thus manipulations of this data result in only small error.

The results of the differential filtration measurement are shown in Fig. 4. For most cases, the cyanobacterial production exhibited a maximum at 30 to $40 \mathrm{~m}$ depth for $\operatorname{Stn} 19$, and $50 \mathrm{~m}$ for $\operatorname{Stn} 10$. This corresponds to about $20 \%$ of surface irradiance. Below this maximum, cyanobacteria account for anywhere from 50 to $100 \%$ of total carbon assimilation. The data of 24 April are the exception to this pattern, showing a maximum at the surface. At Stn 10, production is low with no distinct maximum of cyanobacterial production. In the North Sargasso (north of the STC) cyanobacteria appear to be contributing a greater proportion of the production deeper in the water column. Again, the data of 24 April appear anomalous since there is no reduction of photosynthesis at the surface.

\section{Carbon-specific growth rates}

It has been reported that natural populations of Synechococcus spp. exhibit a diel pattern in the frequency of dividing cells where the highest percentage of dividing cells is found after dusk with low values during the morning (Campbell \& Carpenter 1986a). We found no significant correlation between specific growth rates of Synechococcus spp. and cell abundance ( $r=0.41, n=14$ ) or between the number of paired cells and specific growth rates in a sample $(r=0.21, n=14)$. We also found no significant correlation between cell abundance and number of paired cells $(r=0.02, n=14)$. During Biowatt I, samples for productivity measurements of Synechococcus spp. and cell counts were taken before dawn or during the morning, and this could perhaps explain the lack of correlation between specific growth rates and number of paired cells that we observed.

The carbon-specific production and growth rates based on epifluorescence nuclear-track autoradiography are shown in Table 1. A comparison of growth rates obtained by autoradiography and by differential filtration is shown in Fig. 5. Generally the production rates by microautoradiography underestimate, by a factor of 2 , the rates determined from differential filtration, and this is reflected in the growth rates in Fig. 5. The reason for this descrepancy is probably the aforementioned presence of small eucaryotes in the $<1 \mu \mathrm{m}$ filter fraction. Nevertheless, there is a positive correlation between the 2 methods ( $p \leq 0.05, n=14$ ). The means for the growth rates are $0.7 \mathrm{~d}^{-1}$ for autoradiography and $1.5 \mathrm{~d}^{-1}$ for differential filtration.

These estimates of the growth rates are larger by a factor of almost 10 than the net-cumulative growth rates determined from the increase in cells over the period between visits to $35^{\circ} \mathrm{N}, 70^{\circ} \mathrm{W}$. Since Synechococcus spp. are very small cells and therefore have a negligible sinking rate it is likely that this difference is caused by grazing. We can roughly estimate the grazing loss from the 'true' growth rate determined from the autoradiography, assigning the value
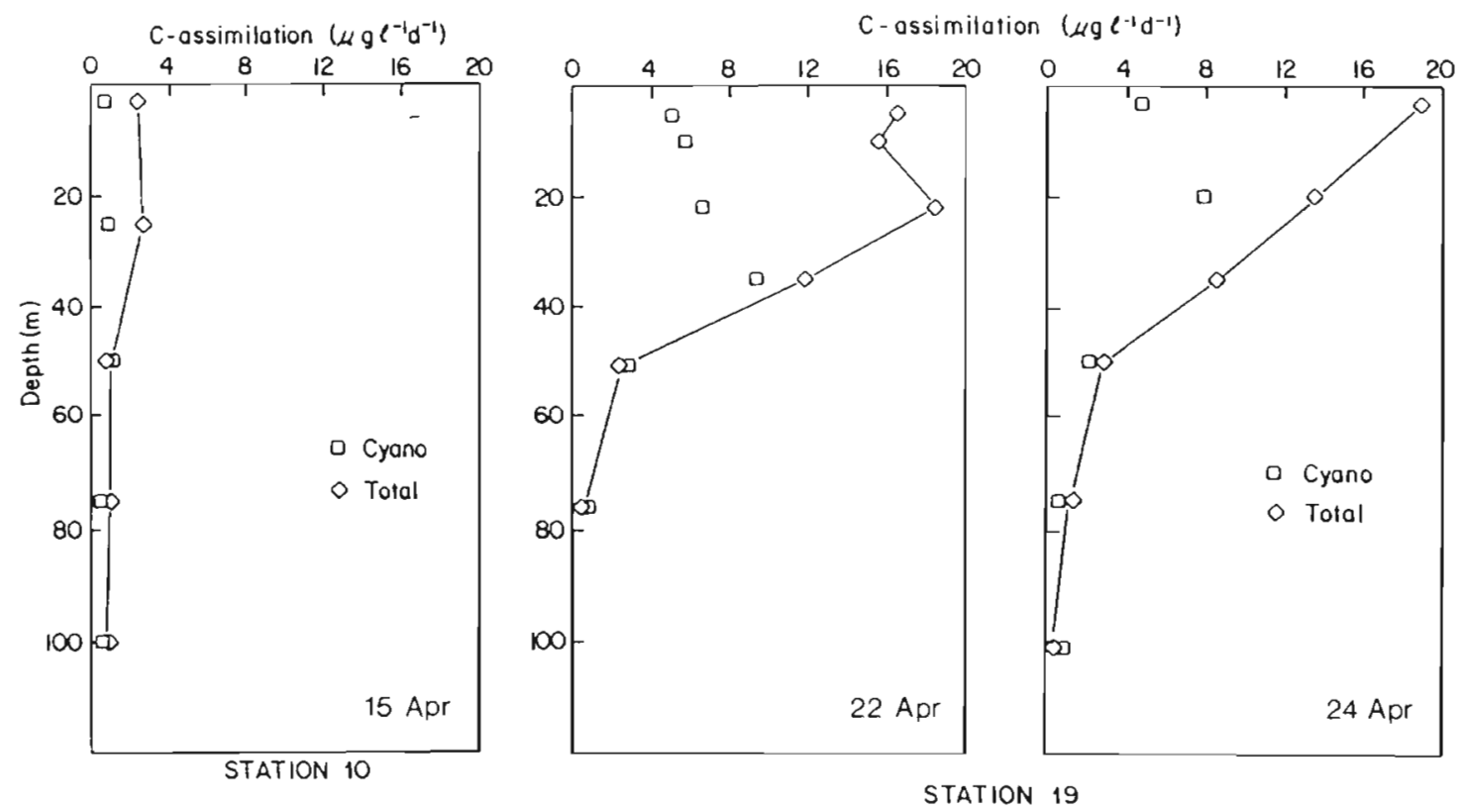

Fig. 4. Photosynthetic carbon assimilation in particulate matter collected on Millipore HA filters ('Total') and that collected by Whatman 934-AH glass fiber filters ('Cyano') as a function of depth for 3 experiments during the cruise 
Table 1. Synechococcus spp. Micro-autoradiographic growth rate determinations on Biowatt I (April 1985) in the northwest Atlantic Ocean. See Fig. 1 for station locations

\begin{tabular}{|ccccc}
$\begin{array}{c}\text { Date } \\
\text { Stn-Cast }\end{array}$ & $\begin{array}{c}\text { Depth } \\
(\mathrm{m})\end{array}$ & $\begin{array}{c}\mathrm{fgC} \\
\text { cell }^{-1} \mathrm{~h}^{-1}\end{array}$ & $\begin{array}{c}\mathrm{fgC} \\
\text { cell }^{-1} \mathrm{~d}^{-1}\end{array}$ & $\begin{array}{c}\text { Growth } \\
\text { rate }\left(\mathrm{d}^{-1}\right)\end{array}$ \\
\hline $13 \mathrm{Apr}$ & 29 & 6.20 & 74.4 & 0.778 \\
$10-19$ & & & & \\
$15 \mathrm{Apr}$ & 8 & 11.78 & 141.36 & 1.176 \\
$10-53$ & 26 & 6.89 & 82.68 & 0.836 \\
& 75 & 6.31 & 75.72 & 0.789 \\
$20 \mathrm{Apr}$ & 3 & 4.88 & 58.56 & 0.655 \\
$19-19$ & 10 & 6.22 & 74.64 & 0.781 \\
& 36 & 4.68 & 56.16 & 0.637 \\
& 52 & 3.95 & 47.40 & 0.559 \\
& 76 & 3.40 & 40.80 & 0.498 \\
22 Apr & 10 & 5.21 & 62.52 & 0.688 \\
$19-50$ & 51 & 8.36 & 100.32 & 0.951 \\
& 75 & 8.78 & 105.36 & 0.981 \\
24 Apr & 3 & 3.82 & 45.84 & 0.545 \\
$19-81$ & 20 & 4.96 & 59.52 & 0.663 \\
& 35 & 11.49 & 137.88 & 1.213 \\
& 50 & 7.79 & 93.48 & 0.908 \\
& 75 & 4.06 & 48.72 & 0.571 \\
\hline
\end{tabular}

from Eq. (3) above,

$$
M=r_{a}-g
$$

where $r_{\mathrm{a}}=$ growth rate determined from autoradiography $\left(0.7 \mathrm{~d}^{-1}\right)$; and $g=$ computed average grazing rate necessary to balance the growth rates. This calculation assumes that the scale of variability in space is large relative to the ca $2 \mathrm{wk}$ sampling interval. Since $M=0.08 \mathrm{~d}^{-1}$ grazing is computed to be $0.62 \mathrm{~d}^{-1}$.

Current information about grazing rates upon chroococcoid cyanobacteria in the ocean is limited to few measurements, and different approaches have

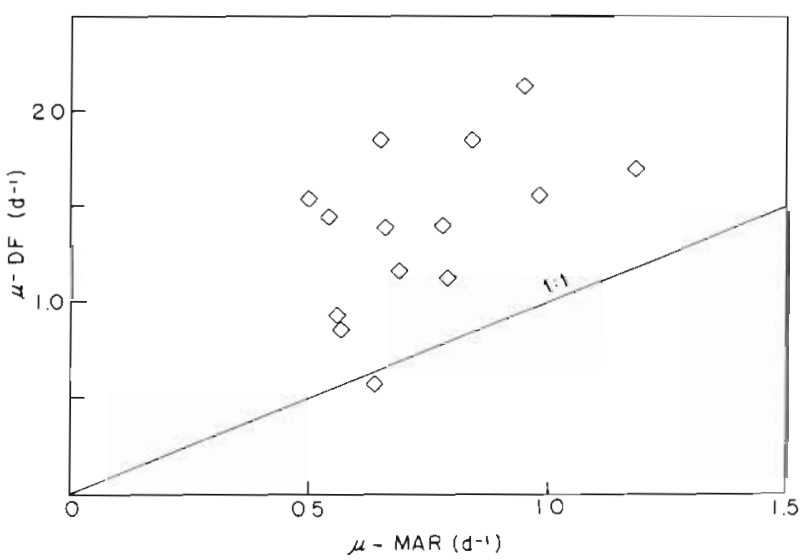

Fig. 5. Comparison of growth rate estimates of cyanobacteria from the differential filtration technique $(\mu-D F)$ and microautoradiagraphy method ( $\mu$-MAR) for all data been used. Landry et al. (1984) report grazing rates of $0.2 \mathrm{~d}^{-1}$ by the seawater dilution culture technique. Iturriaga \& Mitchell (1986) estinate grazing losses of $0.3 \mathrm{~d}^{-1}$ using ${ }^{14} \mathrm{C}$-labelled Synechococcus spp. (clone 'DC-2'). Campbell \& Carpenter (1986b) estimate a grazing rate of $0.35 \mathrm{~d}^{-1}$ at an oceanic warm core eddy and up to $0.83 \mathrm{~d}^{-1}$ at a coastal station. Both these lastmentioned estimates are derived by the dilution culture technique and the use of selective metabolic inhibitors.

To be considered in the evaluation of these rates are the different environments where such measurements are performed as well as the large temporal variability in abundance that chroococcoid cyanobacteria undergo. Such population changes can to a large extent affect the grazing intensity. In spite of the different factors that influence such estimations, the data thus far suggests that a large fraction (ca $40 \%$ ) of the Synechococcus spp. standing crop is consumed daily, The effective metabolic utilization of Synechococcus spp. by micrograzers in the ocean demonstrated by microautoradiography also indicates a significant trophic transfer occurring between cyanobacteria and micrograzers (Iturriaga \& Mitchell 1986). Synechococcus spp. constitute a large fraction of total primary production and are arguably one of the most important primary producers in the oligotrophic ocean. The evidence cited here suggests that they also represent a major link in the transfer of carbon within the pelagic food web.

Acknowledgements. We thank Dave Siegel for suggestions regarding this manuscript. This research was supported by the Office of Naval Research Contracts N00014-86-K-0383 (R. I.), and N00014-84-C0132 and N00014-86-K0204 (J.M.) as part of the Biowatt Project.

\section{LITERATURE CITED}

Campbell, L., Carpenter, E. J., Iacono, V. L. (1983). Identification and enumeration of marine chroococcoid cyanobacteria by immunofluorescence. Appl. environ. Microbiol. 46: $553-559$

Campbell, L., Carpenter, E. J. (1986a). Diel patterns of cell division in marine Synechoccoccus spp. (Cyanobacteria): use of the frequency of dividing cells technique to measure growth rate. Mar. Ecol. Prog. Ser 32: 139-148

Campbell, L., Carpenter, E. J. (1986b). Estimating the grazing pressure of heterotrophic nanoplankton on Synechococcus spp. using the sea water dilution and selective inhibitor techniques. Mar. Ecol. Prog. Ser 33: 121-129

Dickey, T., Siegel, D. A., Boztas, S. H. (1985). Biowatt I XBT data summary. In: Biowatt Newsletter \# 1, October 1985

Douglas, D. J. (1984). Microautoradiography-based enumeration of photosynthetic picoplankton with estimates of carbon-specific growth rates. Mar. Ecol. Prog. Ser 14 $223-228$

Fahnenstiel, G. L., Sicko-Goad, L., Scavia, D., Stoermer, E. F. 
(1986). Importance of picoplankton in Lake Superior. Can. J. Fish. aquat. Sci. 43: 235-240

Fitzwater, S. E., Knauer, G. A., Martin, J. H. (1982). Metal contamination field and laboratory methods of control. Limnol. Oceanogr. 27: 544-551

Fuhrman, J. A., Azam, F. (1982). Thymidine incorporation as a measure of heterotrophic bacterioplankton production in marine surface waters, evaluation and field results. Mar Biol. 66: 109-120

Glover, H. E. (1985). The physiology and ecology of the marine cyanobacteria Synechococcus. In: Jannasch, H. W. Williams, P. J. leB (eds.) Advances in aquatic microbiology, Vol. 3. Academic Press, New York, p. 49-107

Glover, H. E., Campbell, L., Prézelin, B. B. (1986). Contribution of Synechococcus spp. to size fractionated primary productivity in three water masses in the Northwest Atlantic Ocean. Mar. Biol. 91: 193-203

Hobbie, J. E., Daley, R. J., Jasper, S. (1977). Use of nuclepore filters for counting bacteria by fluorescence microscopy. Appl. environ. Microbiol. 33: 1225-1228

Hulburt, E. M. (1964). Succesion and diversity in the plankton flora of the Western North Atlantic. Bull. mar. Sci. Gulf Carib. 14: 34-44

Iturriaga, R., Mitchell, B. G. (1986). Chroococcoid cyanobacteria significant component in the food web dynamics of the open ocean. Mar. Ecol. Prog. Ser 28: 281-297

Johnson, P. W., Sieburth, J. McN (1979). Chroococcoid cyanobacteria in the sea: ubiquitous and diverse phototrophic biomass. Limnol. Oceanogr. 24: 928-935

Johnson, P. W., Sieburth, J. McN. (1982). In situ morphology and occurence of eucaryotic phototrophs of bacterial size in the picoplankton of estuarine and oceanic waters. J. Phycol. 318-327

Knoechel, R., Kalff, J. (1976). Track autoradiography method for the determination of phytoplankton species productivity. Limnol. Oceanogr 21: 583-590

Krempin, D. W., Sullivan, C. W. (1981). The seasonal abun- dance vertical distribution and relative microbial biomass of chroococcoid cyanobacteria at a station in Southern California coastal waters. Can. J. Microbiol. 27: 1341-1344

Landry, M. R., Haas, L. W., Fagerness, V L. (1984). Dynamics of microbial plankton communities: experiments in Kaneohe Bay Hawaii. Mar Ecol. Prog. Ser 16: 127-133

Li, W. K. W., Subba Rao, D. V., Harrison, W G., Smith, J. C., Cullen, J. J., Irwin, B., Platt, T. (1983). Autotrophic picoplankton in the tropical ocean. Science 21 127-133

Murphy, L. S., Haugen, E. M. (1985). The distribution and abundance of phototrophic ultraplankton in the North Atlantic. Limnol. Oceanogr. 30: 47-58

Platt, T., Subba Rao, D. W., Irwin, B. (1983). Photosynthesis of picoplankton in the oligotrophic ocean. Nature, Lond. 301 . $702-704$

Prézelin, B. B., Putt, M., Glover, H. E. (1986). Diurnal patterns in photosynthetic capacity and depth-dependent photosynthesis-irradiance relationships in Synechococcus spp. and larger phytoplankton in three water masses in the Northwest Atlantic Ocean. Mar. Biol. 91: 205-217

Smith, R. C., Baker, K. S., Dustan, P. (1981). Fluorometric techniques for the measurement of oceanic chlorophyll in the support of remote sensing. SIO Ref. 81-17 Univ. of California, La Jolla, p. 1-14

Takahashi, M., Bienfang, P. K. (1983). Size structure of phytoplankton biomass and photosynthesis in subtropical Hawaiian waters. Mar. Biol. 76: 203-211

Waterbury, J. B., Watson, S. W., Guillard, R. R. L., Brand, L. E. (1979). Widespread occurrence of a unicellular marine planktonic cyanobacterium. Nature, Lond. 277: 293-294

Watson, S. W., Novitsky, T J, Quinby, I. C., Valois, F. W. (1977). Determination of bacterial number and biomass in marine environments. Appl. environ. Microbiol. 33: 940-946

Worthington, L. V. (1976). On the North Atlantic Circulation. The John Hopkins Oceanographic Studies 6: 1-110 